\title{
RADIOCARBON AMS DATES FOR PALEOLITHIC CAVE PAINTINGS
}

\author{
H Valladas ${ }^{1,2} \cdot \mathrm{N}$ Tisnérat-Laborde ${ }^{1} \cdot \mathrm{H} \mathrm{Cachier}^{1} \cdot \mathrm{M} \mathrm{Arnold}^{3} \cdot \mathrm{F}^{\text {Bernaldo de Quirós }}{ }^{4}$ • \\ V Cabrera-Valdés ${ }^{5}$ J Clottes ${ }^{6}$. J Courtin ${ }^{7}$. J J Fortea-Pérez ${ }^{8}$ • C Gonzáles-Sainz ${ }^{9}$ • \\ A Moure-Romanillo9
}

\begin{abstract}
Advances in radiocarbon dating by accelerator mass spectrometry (AMS) have made it possible to date prehistoric cave paintings by sampling the pigment itself instead of relying on dates derived from miscellaneous prehistoric remains recovered in the vicinity of the paintings. The work at the Laboratoire des Sciences du Climat et de l'Environnement (LSCE) concentrated on prehistoric charcoal cave paintings from southern France and northern Spain. In most caves, pigment samples were collected from several paintings, and in some instances the sample size allowed for multiple independent measurements on the same figure, so that the coherence of the calculated dates could be tested. Before being dated, each specimen was subjected to a thermal treatment preceded by an acid and basic treatment of intensity commensurate with the sample size.
\end{abstract}

Nine bison drawings from three caves in the Cantabrian region of Spain-two from Covaciella, three from Altamira, and four from El Castillo-were sampled and dated. The 27 dates fell between 13,000 and 14,500 BP, allowing us to attribute the drawings to the Magdalenian period. The 24 dates for 13 drawings in the Cosquer cave indicated two distinct periods of painting activity-one around 28,000 BP and the other around 19,000 BP. The Chauvet cave paintings turned out to be the oldest recorded to date, as five dates fell between 32,000 and 31,000 BP. After discussing the sample preparation protocol in more detail, we will discuss the ages obtained and compare them with other chronological data.

\section{INTRODUCTION}

For over a decade, tandem accelerators at several laboratories have obtained radiocarbon dates for parietal art by dating the pigment. Whereas blood residues (Loy et al. 1990), beeswax (Nelson et al. 1995), or plant resins (Hedges et al. 1988) used in the paintings have been dated, it is wood charcoal used in the production of some of the black paintings that has received the most attention (Russ et al. 1990; Valladas et al. 1992; Igler et al. 1994). Since 1992 we have used the Gif sur Yvette tandem accelerator to date charcoal scrapings from prehistoric cave drawings. The protocol followed in our sample preparation will be discussed briefly, since the details have already been published (Valladas et al. 1999). We will concentrate on the dates spanning a period of almost 20,000 years, which we obtained for prehistoric charcoal drawings in several Spanish and French caves.

\section{PROCEDURE}

To protect the visual integrity of the drawings the pigment was scraped within rock cracks or from the thickest layers, otherwise the same figure was sampled in several places. Unless the painting was done in manganese dioxide, the samples of black pigment, weighing 10-100 mg, contained wood charcoal, sometimes accompanied by calcite grains from the rock face. In some instances the wood could be identified as belonging to the species pinus. Figure 1 shows how the scrapings were treated to eliminate contamination by extraneous carbon (Valladas et al. 1999). The conventional acid and basic treatment of charcoal was more or less rigorous according to the sample size. The residue from

\footnotetext{
${ }^{1}$ Laboratoire des Sciences du Climat et de l'Environnement, UMR CEA-CNRS 1572, F-91198 Gif-sur-Yvette Cedex, France

${ }^{2}$ Corresponding author. Email: Helene.Valladas@1sce.cnrs-gif.fr.

${ }^{3}$ UMS 2004 (CNRS-CEA), Tandetron Bat.30, 91198 Gif-sur-Yvette, France

${ }^{4}$ Universitad de León, Area de Prehistoria, 24071, León, Spain

${ }^{5}$ Universidad Nacional de Educatión a Distancia, c/Senda del Rey, 7, 28040 Madrid, Spain

611 rue du Fourcat 09000 Foix, France

${ }^{7} 100$ Boulevard de la Libération,13004 Marseille, France

${ }^{8}$ Universidad Oviedo, Area de Prehistoria y Arqueologia, 33006 Oviedo, Spain

${ }^{9}$ Universidad de Cantabria, dpto Ciencias Historicas, Avda Los Castros, s/n, 39005 Santander, Spain
}

(C) 2001 by the Arizona Board of Regents on behalf of the University of Arizona

Radiocarbon, Vol 43, Nr 2B, 2001, p 977-986

Proceedings of the 17th International ${ }^{14} \mathrm{C}$ Conference, edited by I Carmi and $\mathrm{E}$ Boaretto 
SAMPLE PREPARATION

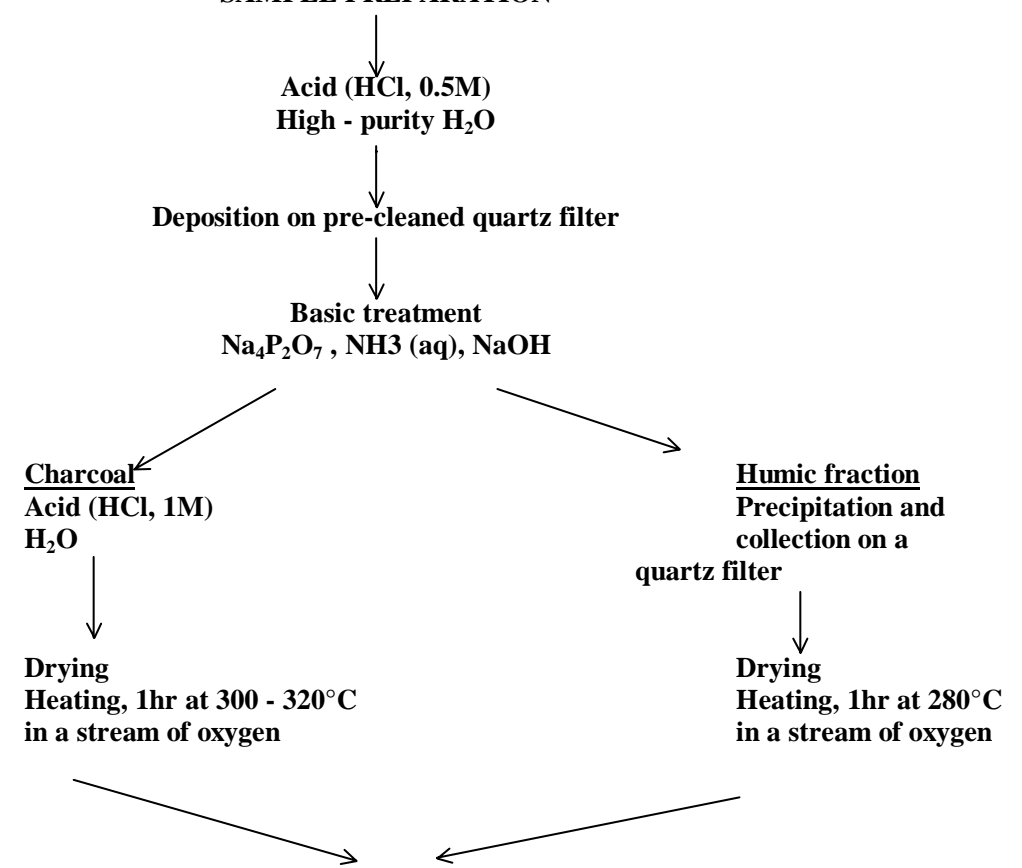

Sample transfered to a combustion tube containing $\mathrm{CuO}$ and $\mathrm{Ag}$ wire and sealed under vacuum

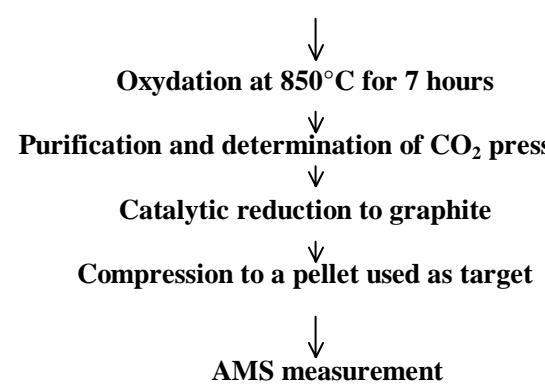

Figure 1 Experimental procedure. The basic treatment is gentle at first, increasing in intensity according to the vulnerability of the sample. We begin with a dilute solution of sodium pyrophosphate whose concentration is increased progressively. Aqueous ammonia of gradually increased concentration is used next, followed by sodium hydroxide treatment in cases of alkali-resistant pigments. As a rule, the treatment stops when the filtrate becomes highly colored. The coloration suggests that not only the outer grain layers have been stripped but that a good fraction of the original charcoal has passed into solution. If the treatment were not interrupted in time, no charcoal might remain for dating. The remaining charcoal grains are washed again with aqueous $\mathrm{HCl}$.

the initial acid bath was retained on a pre-cleaned quartz-frit filter and subjected to subsequent basic and acid washings (see Figure 1 legend). After chemical treatment, the purified charcoal or humic acids collected on the quartz filler were heated in a stream of oxygen for about an hour between 280 and $320{ }^{\circ} \mathrm{C}$ to remove some additional organic contaminants.

Whatever remained was oxidized to $\mathrm{CO}_{2}$ then reduced to graphite and compressed into pellets for the accelerator (Arnold et al. 1987). The purification process eliminated about $90 \%$ of the original mass, leaving us with pellets usually containing from one-half to $1 \mathrm{mg}$ of carbon (Tables 1 and 2, column 3). 
Table 1 Radiocarbon dates for prehistoric paintings at three Spanish caves: Covaciella, Altamira, and El Castillo. Humic acid data are written in italics.

\begin{tabular}{|c|c|c|c|c|c|}
\hline Cave and sample & Lab code & $\begin{array}{c}\text { Dateable } \\
\text { carbon (mg) }\end{array}$ & Date (BP) & $\begin{array}{l}\text { Error } \\
(\mathrm{yr}) 1 \sigma\end{array}$ & $\begin{array}{l}\text { Calibrated age } \\
(2 \sigma)^{\mathrm{a}}\end{array}$ \\
\hline \multicolumn{6}{|l|}{ Covaciella } \\
\hline Bison $25^{\mathrm{b}}$ & $\begin{array}{l}\text { GifA } 95281 \\
\text { GifA } 95370\end{array}$ & $\begin{array}{l}1.4 \\
0.3\end{array}$ & $\begin{array}{l}14,060 \\
13,700\end{array}$ & $\begin{array}{l}140 \\
140\end{array}$ & $\begin{array}{l}17,453-16,309 \\
17,019-15,906\end{array}$ \\
\hline Bison $26^{\mathrm{b}}$ & $\begin{array}{l}\text { GifA } 95364 \\
\text { GifA } 95362\end{array}$ & $\begin{array}{l}2.34 \\
0.3\end{array}$ & $\begin{array}{l}14,260 \\
14,260\end{array}$ & $\begin{array}{l}130 \\
180\end{array}$ & $\begin{array}{l}17,681-16,545 \\
17,750-16,476\end{array}$ \\
\hline \multicolumn{6}{|l|}{ Altamira } \\
\hline Bison XXXIIIc & $\begin{array}{l}\text { GifA } 91181 \\
\text { GifA } 96071 \\
\text { GifA } 91330\end{array}$ & $\begin{array}{l}1.49 \\
1.7 \\
0.53\end{array}$ & $\begin{array}{l}14,330 \\
14,820 \\
14,250\end{array}$ & $\begin{array}{l}190 \\
130 \\
180\end{array}$ & $\begin{array}{l}17,849-16,539 \\
18,361-17,166 \\
17,738-16,465\end{array}$ \\
\hline Bison $\mathrm{XXXVI}^{\mathrm{c}}$ & $\begin{array}{l}\text { GifA } 91179 \\
\text { GifA } 96060 \\
\text { GifA } 91254\end{array}$ & $\begin{array}{l}0.7 \\
2.17 \\
1.38\end{array}$ & $\begin{array}{l}13,940 \\
14,800 \\
14,710\end{array}$ & $\begin{array}{l}170 \\
150 \\
200\end{array}$ & $\begin{array}{l}17,350-16,133 \\
18,361-17,120 \\
18,323-16,948\end{array}$ \\
\hline Bison $\mathrm{XLIV}^{\mathrm{c}}$ & $\begin{array}{l}\text { GifA } 91178 \\
\text { GifA } 96067 \\
\text { GifA } 91249\end{array}$ & $\begin{array}{l}0.87 \\
0.54 \\
0.663\end{array}$ & $\begin{array}{l}13,570 \\
13,130 \\
14,410\end{array}$ & $\begin{array}{l}190 \\
120 \\
200\end{array}$ & $\begin{array}{l}16,939-15,681 \\
16,314-14,682 \\
17,960-16,613\end{array}$ \\
\hline $\begin{array}{l}\text { Magdalenian } \\
\text { bone }\end{array}$ & GifA 90047 & & 14,520 & 260 & $18,195-16,634$ \\
\hline $\begin{array}{l}\text { Engraved bone } \\
\text { El Castillo }\end{array}$ & GifA 90057 & & 14,480 & 250 & $18,129-16,607$ \\
\hline Bison $18 \mathrm{a}^{\mathrm{c}}$ & $\begin{array}{l}\text { GifA } 96079 \\
\text { GifA } 91004 \\
\text { GifA } 96068\end{array}$ & $\begin{array}{l}1.02 \\
0.82 \\
1.05\end{array}$ & $\begin{array}{l}12,620 \\
13,060 \\
13,520\end{array}$ & $\begin{array}{l}110 \\
200 \\
130\end{array}$ & $\begin{array}{l}15,689-14,196 \\
16,351-14,448 \\
16,791-15,713\end{array}$ \\
\hline Bison $18 b^{d}$ & GifA 91172 & 0.69 & 12,910 & 180 & $16,140-14,362$ \\
\hline Bison $18 c^{d}$ & $\begin{array}{l}\text { GifA } 95136 \\
\text { GifA } 95146 \\
\text { GifA } 96077 \\
\text { GifA } 96078 \\
\text { GifA } 95375\end{array}$ & $\begin{array}{l}1.4 \\
1.4 \\
2.05 \\
1.13 \\
0.33\end{array}$ & $\begin{array}{l}10,510 \\
11,270 \\
10,720 \\
10,740 \\
12,390\end{array}$ & $\begin{array}{r}100 \\
80 \\
100 \\
100 \\
190\end{array}$ & $\begin{array}{l}12,926-11,953 \\
13,772-13,010 \\
12,992-12,359 \\
13,000-12,373 \\
15,563-13,845\end{array}$ \\
\hline Bison $19^{d}$ & $\begin{array}{l}\text { GifA } 95227 \\
\text { GifA } 95226 \\
\text { GifA } 98152 \\
\text { GifA } 98151 \\
\text { GifA } 98159\end{array}$ & $\begin{array}{l}1.16 \\
1.36 \\
1.36 \\
0.97 \\
0.34\end{array}$ & $\begin{array}{l}13,520 \\
13,570 \\
13,710 \\
14,090 \\
13,510\end{array}$ & $\begin{array}{l}120 \\
130 \\
140 \\
150 \\
190\end{array}$ & $\begin{array}{l}16,779-15,726 \\
16,851-15,771 \\
17,031-15,917 \\
17,502-16,329 \\
16,867-15,612\end{array}$ \\
\hline Engraved bone ${ }^{\mathrm{d}}$ & OxA 970 & & 10,310 & 120 & $12,821-11,444$ \\
\hline Bone harpoon de & OxA 972 & & 12,390 & 130 & $15,527-13,874$ \\
\hline Bone spearhead & OxA 971 & & 16,850 & 220 & $20,889-19,284$ \\
\hline
\end{tabular}

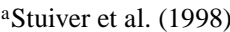

${ }^{b}$ Fortea Perez (1996)

cAlcade del Rio et al. (1911)

${ }^{\mathrm{d}}$ Gowlett et al. (1987) 
Table 2 Radiocarbon dates for prehistoric paintings at two French caves, Cosquer and Chauvet. Humic acid dates are written in italics.

\begin{tabular}{|c|c|c|c|c|}
\hline Cave and sample & Lab code & $\begin{array}{c}\text { Dateable } \\
\text { carbon }(\mathrm{mg})\end{array}$ & Date (BP) & $\begin{array}{l}\text { Error } \\
(\mathrm{yr}) 1 \sigma\end{array}$ \\
\hline \multicolumn{5}{|l|}{ Cosquer ${ }^{a}$} \\
\hline Horse 1 & $\begin{array}{l}\text { GifA } 92416 \\
\text { GifA } 92417 \\
\text { GifA } 92422\end{array}$ & $\begin{array}{l}1.56 \\
0.94 \\
1.23\end{array}$ & $\begin{array}{l}18,840 \\
18,820 \\
18,760\end{array}$ & $\begin{array}{l}250 \\
310 \\
220\end{array}$ \\
\hline Feline & GifA 92418 & 1.52 & 19,200 & 240 \\
\hline Bison 1 & $\begin{array}{l}\text { GifA } 92419 \\
\text { GifA } 92492 \\
\text { GifA } 92423\end{array}$ & $\begin{array}{l}0.64 \\
1.22 \\
0.26\end{array}$ & $\begin{array}{l}18,010 \\
18,530 \\
16,390\end{array}$ & $\begin{array}{l}200 \\
190 \\
260\end{array}$ \\
\hline Megaceros 1 & $\begin{array}{l}\text { GifA } 95135 \\
\text { GifA } 95365\end{array}$ & $\begin{array}{l}1.25 \\
0.12\end{array}$ & $\begin{array}{l}19,340 \\
13,460\end{array}$ & $\begin{array}{l}200 \\
330\end{array}$ \\
\hline Horse 7 & $\begin{array}{l}\text { GifA } 98186 \\
\text { GifA } 98196\end{array}$ & $\begin{array}{l}0.84 \\
0.29\end{array}$ & $\begin{array}{l}19,720 \\
19,740\end{array}$ & $\begin{array}{l}210 \\
340\end{array}$ \\
\hline Deer & GifA 98188 & 0.25 & 19,290 & 340 \\
\hline Star mark & GifA 96075 & 0.87 & 17,800 & 160 \\
\hline Horse 5 & GifA 96072 & 0.84 & 24,730 & 300 \\
\hline Hand 12 & $\begin{array}{l}\text { GifA } 95358 \\
\text { GifA } 95372\end{array}$ & $\begin{array}{l}0.63 \\
0.26\end{array}$ & $\begin{array}{l}24,840 \\
23,150\end{array}$ & $\begin{array}{l}340 \\
620\end{array}$ \\
\hline Bison 2 & $\begin{array}{l}\text { GifA } 96069 \\
\text { GifA } 95195 \\
\text { GifA } 95308\end{array}$ & $\begin{array}{l}1.79 \\
2.04 \\
0.23\end{array}$ & $\begin{array}{l}26,250 \\
27,350 \\
23,080\end{array}$ & $\begin{array}{l}350 \\
430 \\
640\end{array}$ \\
\hline Hand 1 & $\begin{array}{l}\text { GifA } 92409 \\
\text { GifA } 92491 \\
\text { GifA } 92424\end{array}$ & $\begin{array}{l}0.86 \\
1.59 \\
0.44\end{array}$ & $\begin{array}{l}27,110 \\
27,110 \\
26,180\end{array}$ & $\begin{array}{l}430 \\
400 \\
370\end{array}$ \\
\hline Hand 19 & GifA 96073 & 1.30 & 27,740 & 410 \\
\hline Oval mark & GifA 96074 & 2.12 & 28,370 & 440 \\
\hline Soil charcoal & Ly-5558 & & 18,440 & 440 \\
\hline Soil charcoal & GifA 92348 & 2.39 & 20,370 & 260 \\
\hline Soil charcoal & GifA 92349 & 2.17 & 26,360 & 440 \\
\hline $\begin{array}{l}\text { Soil charcoal } \\
\text { Chauvet }^{\mathrm{b}}\end{array}$ & GifA 92350 & 2.06 & 27,870 & 470 \\
\hline Right rhinoceros & $\begin{array}{l}\text { GifA } 95132 \\
\text { GifA } 95133\end{array}$ & $\begin{array}{l}1.40 \\
1.22\end{array}$ & $\begin{array}{l}32,410 \\
30,790\end{array}$ & $\begin{array}{l}720 \\
600\end{array}$ \\
\hline Left rhinoceros & GifA 95126 & 0.80 & 30,940 & 610 \\
\hline Bison & $\begin{array}{l}\text { GifA } 95128 \\
\text { GifA } 95155\end{array}$ & $\begin{array}{l}0.83 \\
0.42\end{array}$ & $\begin{array}{l}30,340 \\
30,800\end{array}$ & $\begin{array}{l}570 \\
1.500\end{array}$ \\
\hline Torch scraping 1 & $\begin{array}{l}\text { GifA } 95129 \\
\text { GifA } 95130 \\
\text { GifA } 95158\end{array}$ & $\begin{array}{l}2.30 \\
1.76 \\
0.308\end{array}$ & $\begin{array}{l}26,980 \\
26,980 \\
25,700\end{array}$ & $\begin{array}{l}410 \\
420 \\
850\end{array}$ \\
\hline Torch scraping 2 & GifA 95127 & 1.22 & 26,120 & 400 \\
\hline Soil charcoal & $\begin{array}{l}\text { Ly-6878 } \\
\text { Ly-118/Oxa } \\
\text { Ly-6879 }\end{array}$ & $\begin{array}{l}5.000 \\
2.500 \\
2.000\end{array}$ & $\begin{array}{l}29,000 \\
24,770 \\
22,800\end{array}$ & $\begin{array}{l}400 \\
780 \\
400\end{array}$ \\
\hline
\end{tabular}


Whenever enough material was available, multiple datings were done on the same drawing to test the reproducibility and coherence of the results, and the humic acid fraction obtained during the basic treatment was also dated to see to what degree the initial pigment sample might have been contaminated (Batten et al. 1986). As will be seen in the next section, the purified charcoal and the humic acid fraction usually yielded similar results. While good agreement between the two sets of dates generally increases one's confidence in the reliability of the dates, one can never exclude a remote possibility that both fractions may have been contaminated somehow. When the two fractions diverge, the humic acid fraction, which one expects to contain more contaminants, tends to give a lower figure. In such cases the age of the purified charcoal is more trustworthy.

The described preparation procedure was previously tested from the Solutrean level of the Abri des Peyrugues on a piece of charcoal that was broken into several pieces. Some pieces were subjected to very strong chemical treatment, others were treated in the same way as the pigment samples, still others subjected to chemical but not thermal treatment. These results show that 1) the strong and weak treatments of the same charcoal gave similar results, and 2) the thermal treatment did eliminate some additional contamination by more recent carbon, since the samples thus treated gave slightly older ages. The results confirmed also the good reproducibility of our protocol (Valladas et al. 1999).

The extent of contamination by modern carbon during sample preparation was determined by subjecting several $>100,000$-yr-old charcoals to the same treatment as our pigment samples. This contamination estimated at $0.50 \pm 0.13 \mathrm{pMC}$, was used to make a suitable correction to the calculated pigment ages.

\section{RESULTS}

\section{Spanish Caves}

We will first discuss the dates obtained for a number of bison painted in three Spanish caves-Covaciella, Altamira, and El Castillo-during the Magdalenian.

Covaciella cave was discovered in 1994 in eastern Asturias at the edge of the Cantabrian region (Fortea-Perez 1996). On the western part of the main panel one finds aligned a female $\left(\mathrm{n}^{\circ} 25\right)$ and a male bison $\left(n^{\circ} 26\right)$ painted in black. These two bison, which are only a few centimeters apart, were sampled within a year of the cave's discovery.

Table 1 lists the dating results. One can see that the purified charcoal obtained from the two bison paintings have virtually the same age, 14,060 \pm 140 and 14,260 $\pm 130 \mathrm{BP}$, respectively. The humic acid (italicized in the table) and purified charcoal fractions of the bison gave ages similar enough to suggest minimal sample contamination.

We have no dates for the associated archaeological material because excavation work has not been completed.

Altamira cave. (Santillana del Maar) in the province of Cantabria has been studied since the 19th century (Bernaldo de Quiros 1994; Moure et al. 1996). On its painted ceiling, about 20 bison are depicted in red and black or only in black (Figure 2). Two adjacent polychrome bison (XXXIII and XXXVI; Breuil and Obermaier 1935) were sampled as well as a black bison (XLIV). Each pigment scraping was divided in two, and each subsample was treated and dated separately (Table 1). The two purified charcoal fractions of bison XXXIII gave comparable ages: 14,330 $\pm 190 \mathrm{BP}$ and $14,820 \pm 130 \mathrm{BP}$, ages close to the $14,250 \pm 180 \mathrm{BP}$ obtained on humic acid fractions (italicized in Table 1). On the other hand, for the other two bison (XXXVI and XLIV) the purified charcoal ages 
were more widely scattered, ranging from 13,100 to $14,800 \mathrm{BP}$, and in some instances younger than the corresponding humic acid fractions (14,710 and 14,410 BP for bison XXXVI and XLIV, respectively). At the moment, we have no simple explanation for these younger dates. The rock-face conditions at Altamira make contamination by old water-borne carbon highly improbable. The same cannot be said for contamination by modern carbon, since the cave has been extensively visited for over a century. The fragility of the collected pigment obliged us to resort to a relatively weak basic treatment, so some younger carbon might have survived. In our opinion, if one assumes that all bison were painted at about the same time and that the design was not retouched at a later date, the older dates $(14,330$ and $14,800 \mathrm{BP})$ are most reliable. In favor of this argument is the fact that bone specimens from the Magdalenian strata were dated to the same age range (see Table 1). Engraved on one of the dated fragments was a deer similar to the deer painted on the ceiling.

El Castillo cave. (Puente Viesgo), also in Cantabria, is located not far from Altamira (Moure et al. 1996). The prehistoric paintings are currently being studied by F Bernaldo de Quiros, V CabreraValdés, A Moure, and C Sainz. The four bison sampled are situated in the same panel of the cave (Figure 3): three of them are bicolored (No 18a and 18b, and 18c; Alcade del Rio et al. 1911): one (18a) has an additional negative hand print and two extra animals, the other (18b) is accompanied by four human hand imprints; the remaining bison (No 19; Alcade del Rio et al. 1911) is exclusively in black. Three dates were obtained for bison 18a, one for 18b, and four dates for each of the other two bison. Only two humic acid fractions obtained on No 19 and 18c were large enough for dating. Bison 18a yielded rather unusual results. A pigment sample from the abdomen was dated to $12,620 \pm 110 \mathrm{BP}$, whereas a scraping from one hind leg gave the dates of $13,060 \pm 200$ and $13,520 \pm 130 \mathrm{BP}$, respectively.

The reason for such a discrepancy is uncertain at the moment. There is no indication that this particular painting was retouched at a later date. As in the case of Altamira cave, one can assume that some of the El Castillo paintings have been contaminated by modern carbon because of their location near the path used today by the numerous visitors to the cave. So, it appears to us that the oldest dates obtained for this bison should be the most relevant. Taking this hypothesis into consideration, we obtained ages ranging between about 13,000 and 13,700 BP for bison 18a, 18b, and 19, which are roughly compatible within $2 \sigma$. It would be interesting in the future to get additional dates for bison $18 \mathrm{~b}$ to check the result obtained so far $(12,910 \pm 180 \mathrm{BP})$, which appears slightly younger than the highest ages obtained for bison 18a and 19. As a matter of fact, it is possible that the age obtained for bison $18 \mathrm{~b}$ was underestimated due to the presence in the charcoal of a small contamination by modern carbon. If it is the case, the time interval for the paintings of these three bison could be made even shorter.

In the case of the fourth bison (18c) purified charcoal gave four dates between 10,500 and $11,300 \mathrm{BP}$, whereas the humic acid fraction yielded a slightly older date of $12,390 \pm 190 \mathrm{BP}$. As for bison XXXVI and XLIV of Altamira, we cannot exclude that these particular samples were more contaminated than the others from the site and that our treatment proved to be inadequate. In that case, the oldest date obtained on the humic fraction $(12,390 \pm 190 \mathrm{BP})$ should be the most relevant for this painting. If so, this bison might have been painted more recently than the three others and have been contemporaneous with a bone harpoon from layer 6 of the same site, which yielded a similar age of 12,390 $\pm 130 \mathrm{BP}$ (Gowlett et al. 1987).

The calibrated ${ }^{14} \mathrm{C}$ dates of the Spanish paintings and of archaeological remains from corresponding sites are compared in Table 1 (Stuiver et al. 1998). At Altamira, most of the paintings and remains found on the ground fall between 18,000 and 16,500 BP. The Covaciella bison fall within the same 


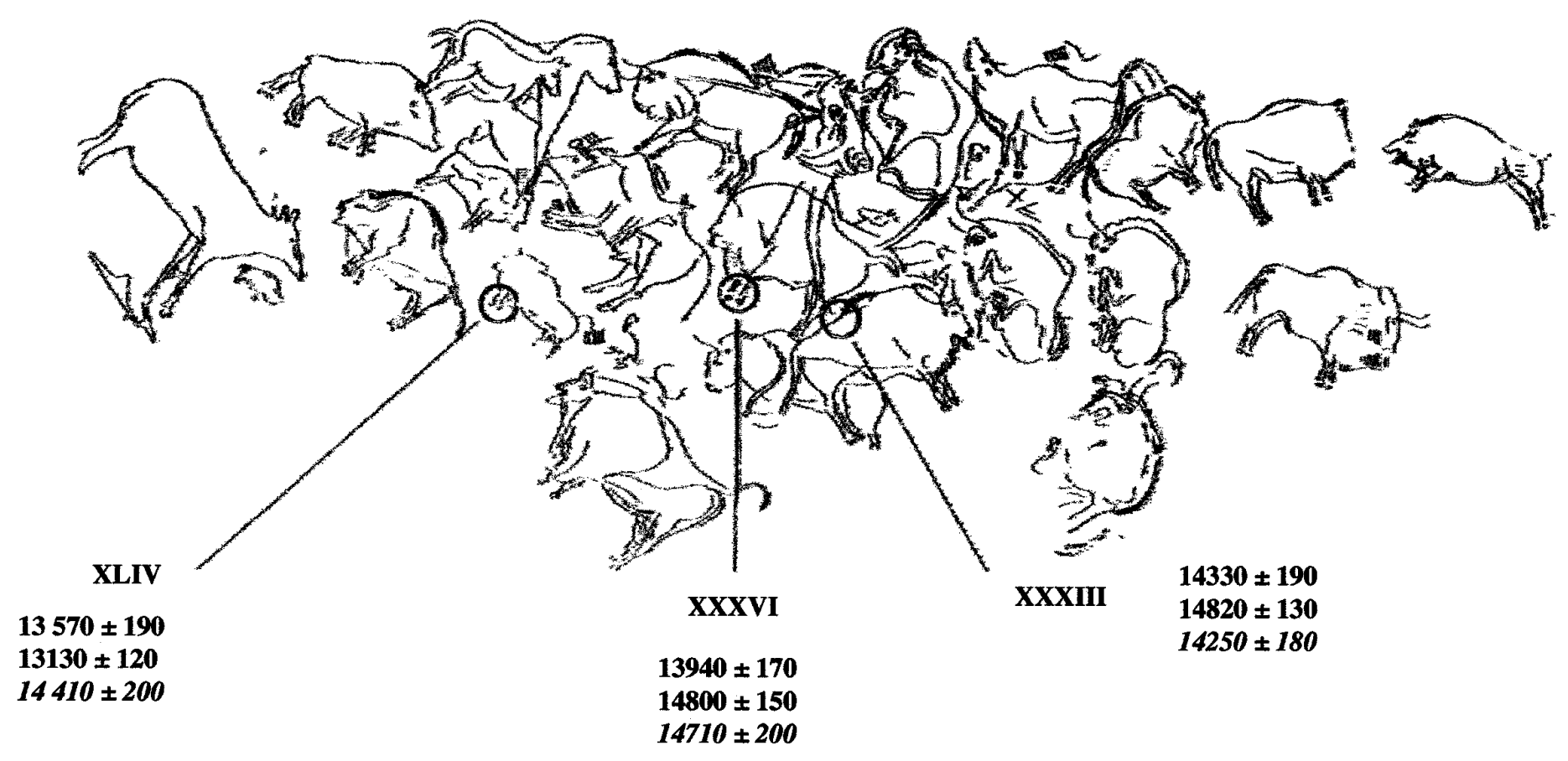

Figure 2 Images from the Altamira painted ceiling (Breuil and Obermaier 1935). The locations of the three dated bison are indicated along with the dates obtained on purified charcoals and humic fractions (in italics). 

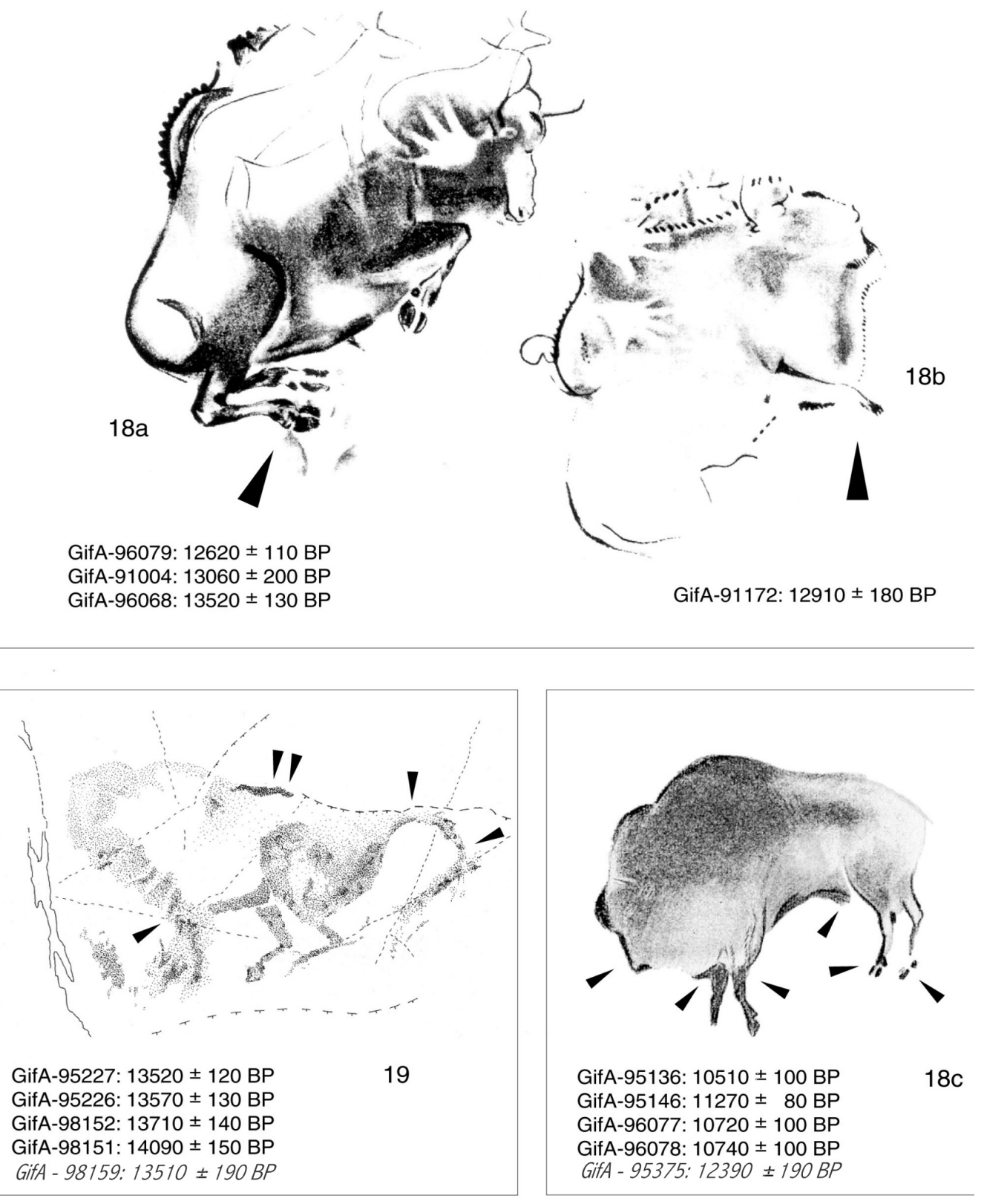

Figure 3 El Castillo panel with the four bison. The locations of the four dated bison are indicated along with the dates obtained on purified charcoals and on humic fractions (in italics). 
age range, and so were probably painted at about the same time. The El Castillo bison appear to be somewhat more recent, since at least three date to between 16,500 and $14,400 \mathrm{BP}$, and the fourth is even younger.

\section{French Caves}

We will now discuss the dates obtained at two recently discovered caves in France. In 1991 scuba divers discovered near Marseilles the Cosquer cave, whose entrance is now $40 \mathrm{~m}$ below sea level. The cave is richly decorated with rock paintings and carvings (Clottes et al. 1992, 1997). About 24 dates were obtained for 13 charcoal drawings: three horses, two bison, a feline, a stag, and a giant deer, as well as three negative hands and two geometric signs (Clottes and Courtin 1994). Table two shows the dating results. As usual, the humic acid fractions yielded similar or slightly lower ages than the purified charcoal. Some pigment scrapings were divided in two and the two halves were treated and dated separately, yielding usually compatible ages at the 1- $\sigma$ level. The paintings can be grouped into two time periods about 10,000 years apart. The first group consisting of negative hands, a bison, and an oval sign, were dated to between 28,000 and 27,000 BP, during the Gravetian period. Except for one horse, the other animals and the star-like sign were dated to between 19,700 and 18,500 BP, during the Solutrean period. Taking into account the amplitude of the errors, it is not possible to conclude if each of the two painting phases lasted a brief period of time or stretched over centuries. However, one of the hands and a horse had an age of about 25,000 BP. Only after additional dates have been obtained will we know whether these two dates represent an intermediate period of cave decoration or if they are the result of more extensive contamination.

The time span that separates the two bison (1 and 2) that are similar and depicted on the same wall is rather surprising. This fact can be interpreted in at least two ways: either the stylistic conventions were maintained over extremely long time periods, or the older one was not created using fresh charcoal. To help us choose between these alternatives additional dates will be needed. It is noteworthy that charcoal fragments collected on ground surface also fall within two distinct time intervals: 1820 and $26-28 \mathrm{ka} \mathrm{BP}$, respectively (see Table 2).

If the Cosquer dates surprised some prehistorians, the surprise was nothing compared to the impact of dates obtained several years later for the parietal art at Chauvet cave discovered in Ardeche in December 1994. It is currently being studied by a multidisciplinary team under the direction of Jean Clottes (Clottes et al. 1995). So far, about a dozen dates have been obtained for two rhinoceroses, a bison, and two torch rubbings.

Most humic-acid fractions yielded dates in good agreement with those obtained on purified charcoal. The animal representations were dated to between about 32,000 and 30,500 BP, within the Aurignacian period (Table 2). The torch scrapings were about 27,000 years old, a date not surprising if one notes that in one case the torch was scraped against a layer of calcite deposited on top of a drawing! Included in Table 1 are ages obtained for charcoal collected on the surface of the ground. The ages ranged from 30 to $20 \mathrm{ka} \mathrm{BP}$, suggesting that the cave must have been visited on several occasions before it was sealed off by a rock-fall. Dates from additional samplings are being processed and will be published in the near future.

\section{CONCLUSION}

Even if the direct dating of cave paintings is still in its infancy, the few dates reported so far have convinced art historians of the need to revise prior ideas about the evolution of prehistoric art. The 
findings at Chauvet cave, in particular, indicate that theories assuming a linear progression from simple to more complex composition have to be discarded.

\section{ACKNOWLEDGMENTS}

We gratefully acknowledge the assistance of M Paterne and E Kaltnecker.

\section{REFERENCES}

Alcalde del Rio H, Breuil H, Sierra L. 1911. Les cavernes de la région cantabrique (Espagne). Monaco: $\mathrm{A}$. Chene.

Arnold M, Bard E, Maurice P, Duplessy JC. 1987. ${ }^{14} \mathrm{C}$ dating with the Gif-sur-Yvette Tandetron accelerator: status report. Nuclear Instruments and Methods in Physics Research B29:120-3.

Batten RJ, Gillespie R, Gowlett JAJ, Hedges REM. 1986. The AMS dating of separate fractions in Archaeology. Radiocarbon 28(2A):698-701.

Bernaldo de Quiros F. 1994. Reflexiones en la Cueva de Altamira. In: Lasheras JA, editor. Homenaje al Dr Joaquin Gonzales Echegaray. Santander: Centro de Investigacion y Museo de Altamira. Monografias 17: 261-7.

Breuil H, Obermaier H. 1935. Cave of Altamira at Santillana del Maar, Spain. Madrid: Duque de Berwick y Alba.

Clottes J, Courtin J, Valladas H, Cachier H, Mercier N, Arnold M. 1992. La grotte Cosquer datée, Bulletin Société Préhistorique Française 89(8):230-4.

Clottes J, Courtin J. 1994. La grotte Cosquer. Edition Seuil. Paris.

Clottes J, Chauvet JM, Brunel-Deschamps E, Hillaire C, Daugas JP, Arnold M, Cachier H, Evin J, Fortin P, Oberlin C, Tisnérat N, Valladas H. 1995. Les peintures paléolithiques de la grotte Chauvet-Pont d'Arc, à Vallon- Pont-d'Arc (Ardèche, France): datations directes et indirectes par la méthode du radiocarbone. Paris. $C$. R. Acad. Sc. 320(IIa):1133-40.

Clottes J, Collina-Girard J, Arnold M, Valladas H. 1997. News from Cosquer Cave; climatic studies, recording, sampling, dates. Antiquity 71(272):321-6.

Fortea Perez FJ. 1996. La grotte de Covaciella (Carena de Cabrales, Asturies, Espagne). INORA 13: 1-3.

Gowlett JAJ, Hedges REM, Houseley RA, Law IA, Perry C. 1987. Radiocarbon dates from the Oxford AMS system: datelist 6. Archaeometry 29(2):289-306.

Hedges REM, Bronk Ramsey C, van Klinken GJ, Pettitt PB, Nielsen-Marsh C, Etchegoyen A, Fernadez Niello JO, Boschin MT, Llamazares AM. 1988. Methodolog- ical issues in the ${ }^{14} \mathrm{C}$ dating of rock painting. Radiocarbon 40(1):35-44.

Igler W, Dauvois M, Hyman M, Menu M, Rowe M, Vezian J, Walter P. 1994. Datation radiocarbone de deux figures pariétales de la grotte du Portel (Commune de Loubens, Ariège). Bulletin Société Préhistorique Ariège-Pyrénées XLIX:231-6.

Loy TH, Jones R, Nelson DE, Meehan B, Vogel J, Southon J, Cosgrove R. 1990. Accelerator radiocarbon dating of human blood proteins in pigments from Late Pleistocene art sites in Australia, Antiquity 64:110-6.

Moure Romanillo A, Gonzales Sainz C, Bernaldo de Quiros F, Cabrera Valdes V. 1996. Dataciones absolutas de pigmentos en cuevas cantabricas: Altamira, El Castillo, Chimeneas y Las Monedas. In: Moure Romanillo A, editor. "El Hombre Fosil" 80 Anos Despues. Santander. p 295-324.

Nelson DE, Chaloupka G, Chippindale C, Alderson MS, Southon JR. 1995. Radiocarbon dates for beeswax figures in the prehistoric rock art of Northern Australia. Archaeometry 37(1):151-6.

Russ J, Hyman M, Shafer J, Rowe MW. 1990. Radiocarbon dating of prehistoric rock paintings by selective oxydation of organic carbon. Nature 348(20/27):710-1.

Stuiver M, Reimer PJ, Bard E, Beck JW, Burr GS, Hughen KA, Kromer B, McCormac FG, van der Plicht J, Spurk M. 1998. INTCAL98 radiocarbon age calibration, 24,000-0 cal BP. Radiocarbon 40(3):1041-83.

Valladas H, Cachier H, Maurice P, Bernaldo de Quiros F, Clottes J, Cabrera Valdes V, Uzquiano P, Arnold M. 1992. Direct radiocarbon dates for prehistoric paintings at the Altamira, El Castillo and Niaux caves. $\mathrm{Na}$ ture 357:68-70.

Valladas H, Tisnérat N, Cachier H, Arnold M. 1999. Datation directe des peintures préhistoriques par la méthode du carbone 14 en spectrométrie de masse par accélérateur, Actes du Colloque "C14 et Archéologie", 1998. Mémoires de la Société Préhistorique Française, Tome XXVI et Supplément 1999 de la Revue d'Archéométrie. p 39-44. 